\title{
THOUGHTS OF INTRODUCTION OF EDITOR-IN-CHIEF
}

It will soon be 30 years since Atlanti had first seen the light of the world. Atlanti were published by the Archival Center for Professional and Technical Issues (founded in 1985) as part of the Provincial Archives in Maribor. The issue of the first number of Atlanti was postponed from 1990 to the year 1991 due to the independence of the Republic of Slovenia and the initial problems that arose in preparations of publishing the first number. I looked at the first number of Atlanti with great interest, since in 1991, as the editor-in-chief of the journal, I claimed that solving professional and technical problems in the archives are some of the most comprehensive areas of archival theory and practice, no matter where the archives operate. The first efforts of the Atlanti publication were to draw attention to the issues of adaptation of existing buildings for the purposes of the archives. Several authors addressed these questions in their contributions. Those were Dr. Ugo Cova from State Archives in Trieste, Italy, Dr. Peter Pavel Klasinc from Provincial Archives Maribor, Slovenia, Dr. Marco Carassi and Dr. Izabella Massabo Ricci from the State Archive in Turin, Italy, Dr. Gerald Gaenser from the Styrian Regional Archives in Graz, Austria, Dr. Long Yuchuen from China, Dr. Edward Fracki from Archives in Warsaw, Poland, Dr. Josef Marsal from Archives in Prague, Czech Republic, and Daniele Neirinck from Directorate of French Archives, France.

The introduction of the first number of Atlanti was written by the Chairperson of the Assembly of Correspondents (today members) Prof. Dr. Simonida Marjanovič. In her article 'Why Atlanti?' she substantiated the need of such publication and thanked the International Council of Archives, Dr. Michael Duchein, Chairman of the Committee for Buildings and Equipment, and the Director General of the International Council of Archives, Prof. Dr. Charles Kecskemeti.

Editorial Board of Atlanti No. 1 consisted of Dr. Gerald Gaenser, Dr. Ken Hall, Dr. Herman Rumschoettel, Miroslav Novak and Zdenka Rajh. The Center consisted of 13 correspondents (today members) from different countries: Roana de Andres, Spain, Gerald Gaenser, Austria, Dr. Ugo Cova, Italy, Ken Hall, United Kingdom, Edvard Fracki, Poland, Shen Lihua, China, Josef Marsal, Czechoslovakia, Irina Grigorievna Shepilova, Russia, Imre Ress, Hungary, Ventsislav Veltschev, Bulgaria, Hermann Rumschoettel, Germany, Daniel Neirinck, France and Dr. Peter Pavel Klasinc, Slovenia.

Fortunately, many correspondents were invited to the 12th International Congress of Archives in Montreal, Canada, 1992, and on this occasion we prepared a special edition of Atlanti No. 1, with additional presentation of archives in Slovenia. The follower of Archival Center had already prepared this issue in 1992 for Professional and Technical Issues, which was the International Institute of Archival Science at the Regional Archives of Maribor.

Today, I will try to answer the question from over 30 years ago - "Why Atlanti," posed by Dr. Simonide Marjanovič. (c) ATLANTI + as the International Scientific Review for Contemporary Archival Theory and Practice, are created in order to be able to be placed in a global database. This can be achieved only if we meet the strict criteria required in this process. Existing Atlanti (this year's was the 29th year) will continue to be published as a Journal of Contemporary Archival Theory and Practice in which archivists from all parts of the world, who will attend the annual International Conference "Archival Day," will also be published in their national languages, in the same way this has been done so far. 
In (c) ATLANTI +, independent research scientific texts, mainly members of the International Institute of Archival Science, as well as other scientists from the field of archival science, will be published. They will be published three times a year, entirely in English, under the careful management of the Editor-in-Chief, of five co-managers and $25 \mathrm{mem}$ bers of the Editorial Board from different countries, with only two members from each country. International scientific journal for contemporary archival theory and practice (c) ATLANTI + will be published in classical and digital forms.

When 30 years ago I was preparing the first number of Atlanti, my honorable colleague Prof. Charles Kecskemeti kindly pointed out that we have to have registered authors for at least 5 years ahead to issue a magazine. I acknowledge his comment also today, when I decided on the latest issue of ATLANTI + in that many regular members of the institute and experts in archival science at the AMEU-ECM or related institutions from around the world promised me that they would be happy to contribute to this new magazine ATLANTI +.

So let me conclude with the well-known and often written Latin saying: "Archivistica amor noster, semper et in aeternum"; in conjunction with "Per aspera ad astra" I add, »vivat, crescat, floreat (c) ATLANTI +«.

Assoc. Prof. Dr. Peter Pavel Klasinc, archival councillor Director of the International Institute for Archival Sciences Trieste-Maribor, Trieste, Italy Dean of Archives and Records Management Studies at Alma Mater Europaea - European Center Maribor 